\title{
Ex vivo stimulation of whole blood as a means to determine glucocorticoid sensitivity
}

This article was published in the following Dove Press journal:

Journal of Inflammation Research

2I August 2012

Number of times this article has been viewed

\author{
Christopher Burnsides ${ }^{1, *}$ \\ Jacqueline Corry',* \\ Jacob Alexander' \\ Catherine Balint ${ }^{\prime}$ \\ David Cosmar' \\ Gary Phillips ${ }^{2}$ \\ Jeanette I Webster \\ Marketon ${ }^{1,3}$ \\ 'Division of Pulmonary, Allergy, \\ Critical Care and Sleep Medicine, \\ Department of Internal Medicine, \\ ${ }^{2}$ Center for Biostatistics, ${ }^{3}$ Institute \\ for Behavioral Medicine Research, \\ Wexner Medical Center at The Ohio \\ State University, Columbus, $\mathrm{OH}$, USA \\ * $\mathrm{JC}$ and $\mathrm{CB}$ have equally contributed \\ to this work
}

Correspondence: Jeanette I Webster Marketon

Rm 219 Institute for Behavioral Medicine Research, 460 Medical Center Drive,

Columbus, $\mathrm{OH} 43210$, USA

$\mathrm{Tel}+\mathrm{I} 6142933496$

Fax +I 6I4 3662074

Email jeanette.marketon@osumc.edu
Purpose: Glucocorticoids are commonly prescribed to treat a number of diseases including the majority of inflammatory diseases. Despite considerable interpersonal variability in response to glucocorticoids, an insensitivity rate of about $30 \%$, and the risk of adverse side effects of glucocorticoid therapy, currently no assay is performed to determine sensitivity.

Patients and methods: Here we propose a whole blood ex vivo stimulation assay to interrogate known glucocorticoid receptor (GR) up- and downregulated genes to indicate glucocorticoid sensitivity. We have chosen to employ real-time PCR in order to provide a relatively fast and inexpensive assay.

Results: We show that the GR-regulated genes, GILZ and FKBP51, are upregulated in whole blood by treatment with dexamethasone and that LPS-induction of cytokines (IL-6 and TNF $\alpha$ ) are repressed by dexamethasone in a dose responsive manner. There is considerable interpersonal variability in the maximum induction of these genes but little variation in the $\mathrm{EC}_{50}$ and $\mathrm{IC}_{50}$ concentrations. The regulation of the GR-induced genes differs throughout the day whereas the suppression of LPS-induced cytokines is not as sensitive to time of day.

Conclusion: In all, this assay would provide a method to determine glucocorticoid receptor responsiveness in whole blood.

Keywords: glucocorticoid responsiveness, gene regulation, nuclear receptor, GILZ, FKBP51, cytokines

\section{Introduction}

Glucocorticoids have been used in the treatment of many inflammatory diseases, such as rheumatoid arthritis, asthma, multiple sclerosis, and inflammatory bowel disease since the 1940s. Glucocorticoids are one of the most widely prescribed drugs. It has been suggested that $1 \%-3 \%$ of the adult population currently uses glucocorticoids. ${ }^{1}$

Glucocorticoids are potent regulators of various aspects of immunity. ${ }^{2}$ They function through a cytosolic receptor, the glucocorticoid receptor (GR), which is a member of the nuclear hormone receptor superfamily. GR binds to DNA to modulate gene transcription. ${ }^{3}$ Upon ligand binding, GR dissociates from a protein complex that includes heat shock proteins and immunophilins. It then dimerizes and translocates to the nucleus where it binds to specific DNA sequences called glucocorticoid response elements to activate gene transcription. ${ }^{4} \mathrm{GR}$ also interferes with other signaling pathways, such as activator protein-1 and nuclear factor kappa $\mathrm{B}(\mathrm{NF \kappa B})^{5}$ to repress gene transcription. It is by this repression of these pro-inflammatory pathways that many of the anti-inflammatory actions of glucocorticoids are mediated. 
Despite their usefulness, glucocorticoid treatment is not without risk. Serious side effects include osteoporosis, adrenal insufficiency, glaucoma, cataracts, and hypertension. ${ }^{6}$ Glucocorticoid use has also been associated with increased risk of some cancers, ${ }^{7}$ cardiovascular disease, ${ }^{8}$ fractures, ${ }^{9}$ and infections. ${ }^{10}$ Glucocorticoid resistance, inherited or acquired, is a major problem in the treatment of many diseases including asthma, ulcerative colitis, systemic lupus erythematosus, and rheumatoid arthritis, with patients exhibiting glucocorticoid resistance being reported as high as $30 \% .{ }^{11-16} \mathrm{In}$ addition, it is also estimated that $30 \%$ of a normal healthy population is glucocorticoid nonresponsive. ${ }^{17}$

Clinical tests are typically not performed prior to prescription of glucocorticoids. Most clinical decisions are based on cortisol measurements as is used in the treatment of sepsis. ${ }^{18}$ However, studies have suggested that steroid bioavailability does not predict clinical outcomes. ${ }^{19}$ Assays to determine GR function have been suggested in the literature. These include the dexamethasone suppression test, ${ }^{20-26}$ inhibition of peripheral blood mononuclear cell (PBMC) proliferation, ${ }^{20,27-30}$ quantification of number and affinity of GRs in PBMCs, ${ }^{20,30,31}$ glucocorticoid suppression of lipopolysaccharide (LPS)-induced genes (primarily cytokines) in alveolar macrophages and PBMCs or blood, ${ }^{21,24-26,30,32-37}$ genome-wide promoter-based bioinformatics analysis of transcriptional activity, ${ }^{38}$ glucocorticoid-induced cutaneous vasoconstrictor (skin blanching), ${ }^{21,39}$ and glucocorticoidinduced gene expression. ${ }^{26,29,30}$

Here we propose an assay to test GR function particularly for the use of glucocorticoids in the treatment of inflammatory diseases. We propose interrogation of both known GR upregulated as well as downregulated genes. Although many anti-inflammatory actions of glucocorticoids are mediated through their ability to downregulate immune factors, they also upregulate genes that are involved in the regulation of inflammation such as glucocorticoid inducible leucine zipper (GILZ), which inhibits the NFKB pathway, ${ }^{40-43}$ and mitogen activated protein kinase phosphatase 1 (MKP-1). ${ }^{44}$ We have proposed to use whole nonseparated blood and real-time polymerase chain reaction to make the assay relatively quick and affordable.

\section{Material and methods}

\section{Ex vivo stimulation of whole blood}

Normal healthy human blood samples were obtained in lavender Hemogard stopper venous blood collection tubes with spray-dried K2 EDTA (10.8 mg) (ThermoFisher Scientific, Pittsburgh, PA) after informed written consent was obtained, as approved by the Institutional Review Board. The demographics of the subjects are shown in Table 1. Three milliliters blood was diluted 1:1 with phosphate buffered saline and triplicates of $500 \mu \mathrm{L}$ aliquots were either untreated or treated with $100 \mathrm{nM}$ dexamethasone (SigmaAldrich, St Louis, MO), $1 \mathrm{ng} / \mathrm{mL}$ LPS (Sigma-Aldrich), or a combination of dexamethasone and LPS for 2 hours at $37^{\circ} \mathrm{C}$. Following incubation, red blood cells (RBC) were lysed by addition of $3 \mathrm{~mL}$ of $\mathrm{RBC}$ lysis buffer $\left(5 \mathrm{M} \mathrm{NH}_{4} \mathrm{Cl}, 5 \mathrm{M}\right.$ $\mathrm{KHCO}_{3}, 1 \mathrm{mM}$ EDTA) for 15 minutes at room temperature and centrifugation at $1400 \mathrm{rpm}$ for 10 minutes. The pellet was washed twice more with $500 \mu \mathrm{L} \mathrm{RBC}$ lysis buffer and centrifuged for 2 minutes at $3000 \mathrm{rpm}$ to ensure removal of all hemes. The pellets were resuspended in $400 \mu \mathrm{L}$ of Ribozol RNA extraction reagent (ISC BioExpress, Kaysville, UT).

\section{Quantification of GR-regulated genes by real-time PCR}

Total RNA was extracted using the Ribozol RNA extraction reagent following the manufacturer's instructions with the following modifications. Volumes were adjusted to fit the $400 \mu \mathrm{L}$ volume of Ribozol, and the isopropanol precipitation step was allowed to proceed overnight at $-20^{\circ} \mathrm{C}$. In addition, $75 \%$ ethanol was chilled before washing the pellet and an additional 1 minute centrifugation at $7500 \times \mathrm{g}$ was added to remove excess ethanol. Five hundred nanograms RNA was reverse transcribed using the High-Capacity cDNA Reverse Transcription kit (Applied Biosystems, Carlsbad, CA). Twenty microliters of cDNA was diluted by addition of $100 \mu \mathrm{L}$ DEPC-treated water. Real-time PCR was performed on $8 \mu \mathrm{L}$ diluted cDNA in a $20 \mu \mathrm{L}$ reaction volume containing $1 \mathrm{X}$ Power $\mathrm{SYBR}^{\circledR}$ Green PCR master mix (Applied Biosystems) and $0.125 \mu \mathrm{M}$ of each primer (Table 2). The following protocol was used on the ABI 7300 real-time PCR system (Applied Biosystems): heated to $50^{\circ} \mathrm{C}$ for 2 minutes, denatured for 10 minutes at $50^{\circ} \mathrm{C}$, and then subjected to 40 cycles of $95^{\circ} \mathrm{C}$ for 15 seconds and $60^{\circ} \mathrm{C}$ for 1 minute. Duplicate cycle threshold $(\mathrm{Ct})$ values of triplicate samples were analyzed using the comparative $\mathrm{Ct}(\Delta \Delta \mathrm{Ct})$ method (Applied Biosystems). The fold induction $\left(2^{-\Delta \Lambda} \mathrm{Ct}\right)$ was obtained by normalizing to two endogenous genes, glyceraldehyde-3-phosphate dehydrogenase (GAPDH) and cyclic AMP-accessory protein (CAP-1), ${ }^{45}$ and expressed relative to

Table I Demographics of normal human subjects $(n=12)$

\begin{tabular}{ll}
\hline Age, mean \pm I SD & $\mathbf{3 2 . 7} \pm \mathbf{7 . 3}$ years \\
\hline Sex & 8 female/4 male \\
Race & 10 Caucasian/I Asian/l other \\
\hline
\end{tabular}

Abbreviation: SD, standard deviation. 
Table 2 Real-time PCR primers

\begin{tabular}{lll}
\hline Target & Forward primer $\left(5^{\prime}-3^{\prime}\right)$ & Reverse primer $\left(5^{\prime}-3^{\prime}\right)$ \\
\hline GILZ & gcacaatttctccatctccttctt & tcagatgattcttcaccagatcca \\
FKBP5I & tccctcgaatgcaactctct & aaacatccttccaccacagc \\
FLAP & gcgtttgctggactgatgta & aatatgccagcaacggacat \\
MKP-I & ctgccttgatcaacgtctca & acccttcctccagcattctt \\
\hline
\end{tabular}

Abbreviations: GILZ, glucocorticoid inducible leucine zipper; FKBP5I, FK506 binding protein 5I; FLAP, arachidonate 5-lipoxygenase-activating protein; MKP-I, mitogen activated protein kinase phosphatase I.

the amount in nontreated cells (GR-induced genes) or LPS only treated cells (GR repressed genes).

\section{Interleukin 6 (IL-6) enzyme-linked immunosorbent assay (ELISA) methods}

Whole blood was stimulated as above for 24 hours. Serum was then separated by centrifugation at $10,000 \times \mathrm{g}$ for 10 minutes. Serum was stored at $-80^{\circ} \mathrm{C}$ until assayed. IL-6 was assayed by ELISA using the Human IL-6 ELISA MAX Set Deluxe Kit (Biolegend, San Diego, CA) according to manufacturer's instructions.

\section{Statistical methods}

In this descriptive study summary statistics (coefficient of variation $[\mathrm{CV}]$, median, and the interquartile range [IQR]) are presented as box plots in Figures 1 and 2 (Table 3). A CV greater than one is considered to have a high degree of variability relative to its mean. For Figures 3-5 the median and the IQR are presented as summary statistics (Table 4). Random-effect linear regression was used to estimate the slope over time or over pre- and post-treatment. Random effects were used since observations are nested within a particular subject. This method takes into account the variability within and between patients and uses this inherent correlation when estimating the standard errors that are used to test slope coefficients. As this study was descriptive in nature, no inferential test comparing different groups were run. All analyses were run using Stata software (v 12.0; Stata Corporation, College Station, TX).

\section{Results}

\section{Interpersonal variations in GR function in whole blood}

Whole blood, drawn from 12 normal healthy volunteers at $8: 30$ am \pm 1 hour who had not eaten for 1 hour prior to the blood draw, was stimulated ex vivo with $100 \mathrm{nM}$ dexamethasone (Figure 1A) or with $1 \mathrm{ng} / \mathrm{mL}$ LPS in the presence and absence of $100 \mathrm{nM}$ dexamethasone (Figure 1B) for 2 hours. RNA was isolated and the expression of the known GR upreg-

\section{A}

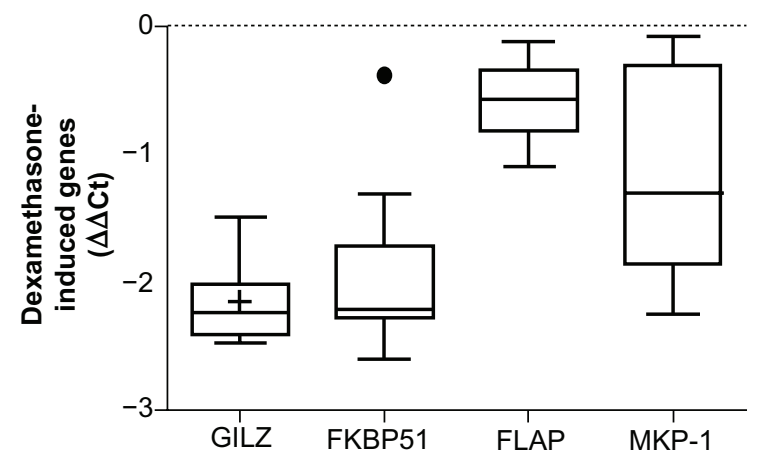

B

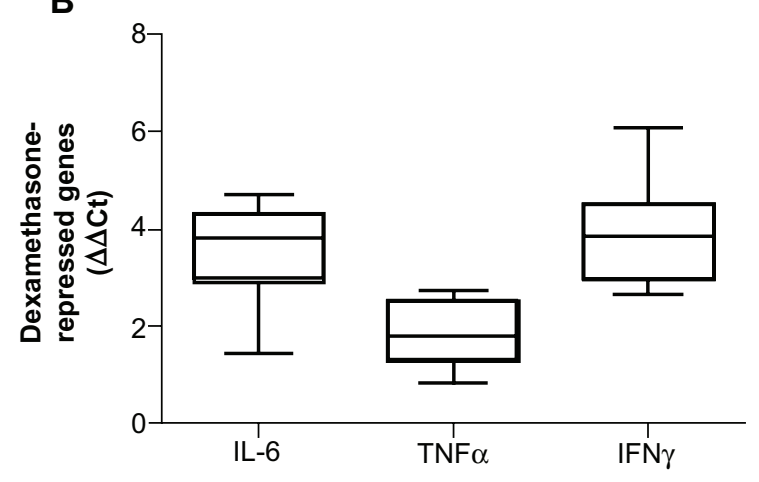

Figure I Whole blood was stimulated with $100 \mathrm{nM}$ dexamethasone $(\mathbf{A})$ or I ng/mL LPS with and without $100 \mathrm{nM}$ dexamethasone (B) for 2 hours. RNA was isolated and CDNA transcribed. Real-time PCR was performed to determine expression of the GR upregulated genes GILZ, FKBP5I, FLAP, and MKP-I (A) and the GR downregulated genes IL-6, TNF $\alpha$, and IFN $\gamma(\mathbf{B})$. The expression of these genes was normalized to the housekeeping genes GAPDH and CAP-I. $\triangle \Delta \mathrm{Ct}$ was calculated for GILZ, FKBP5I, FLAP, and MKP-I as treatment (dexamethasone) against no treatment $(\mathbf{A})$ and for IL-6, TNF $\alpha$, and IFN $\gamma$ as treatment (dexamethasone + LPS) against LPS only.

Note: Box plots with whiskers identifying outliers I.5 times the IQR either above the 3rd quartile or below the Ist quartile are shown from 12 individuals.

Abbreviations: LPS, lipopolysaccharide; PCR, polymerase chain reaction; GR, glucocorticoid receptor; GILZ, glucocorticoid inducible leucine zipper; FKBP5I, FK506 binding protein 5I; FLAP, arachidonate 5-lipoxygenase-activating protein; MKPI, mitogen activated protein kinase phosphatase I; IL-6, interleukin 6; TNF $\alpha$, tumor necrosis factor $\alpha$; IFN $\gamma$, interferon $\gamma$; IQR, interquartile range; CAP-I, cyclic AMPaccessory protein; GAPDH, glyceraldehyde-3-phosphate dehydrogenase.

ulated genes - GILZ, FK506 binding protein 51 (FKBP51), arachidonate 5-lipoxygenase-activating protein (FLAP; also known as ALOX5AP), and MKP-1 - and the known GR downregulated genes - IL-6, tumor necrosis factor $\alpha$ (TNF $\alpha$ ) and interferon $\gamma($ IFN $\gamma)$ - were determined by real-time PCR. As can be seen in Figure 1A, $100 \mathrm{nM}$ dexamethasone induced GILZ, FKBP51, FLAP, and MKP-1 with considerable interpersonal variation. GILZ was induced 3-6-fold (coefficient of variance [CV] of 0.149), FKBP51 was induced 1-6-fold (CV of 0.306), FLAP was induced 1-2-fold (CV of 0.46) and MKP-1 was induced 1-5-fold (CV of 0.462 ). In addition, dexamethasone suppression of LPS-induced IL-6, TNF $\alpha$, and IFN $\gamma$ also showed considerable interpersonal variation. LPS-induced IL-6 was repressed by $100 \mathrm{nM}$ dexamethasone 
A

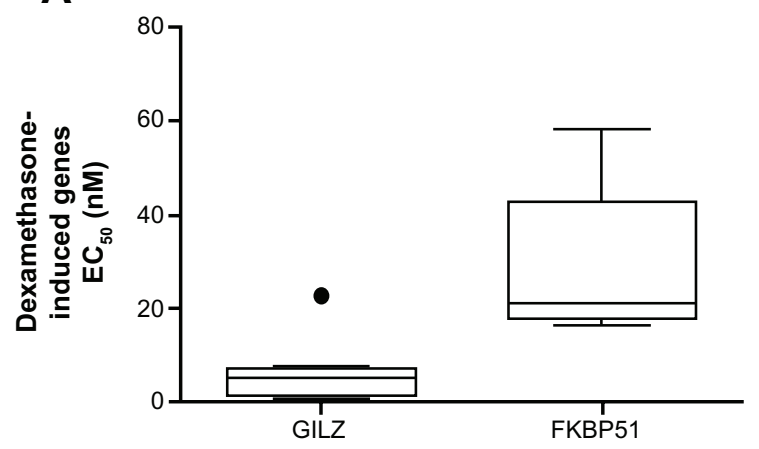

B

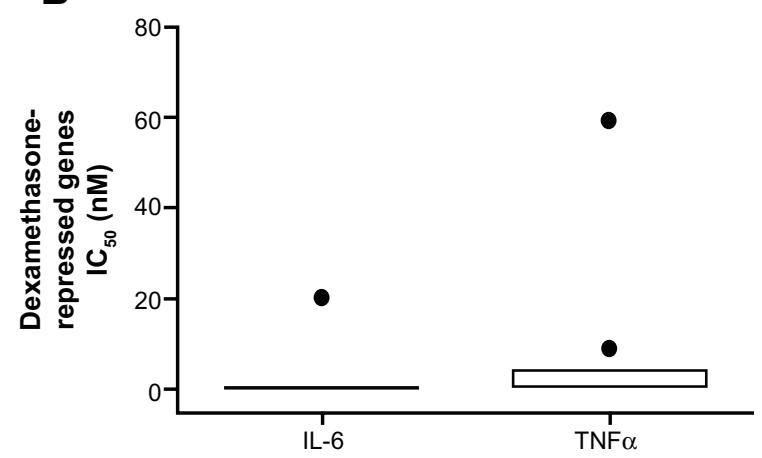

Figure 2 Whole blood was stimulated with increasing amounts of dexamethasone (A) or I ng/mL LPS with and without increasing concentrations of dexamethasone (B) for 2 hours. RNA was isolated and CDNA transcribed. Real-time PCR was performed to determine expression of the GR upregulated genes GILZ and FKBP5I (A) and the GR downregulated genes IL-6 and TNF $\alpha$ (B). The expression of these genes was normalized to the housekeeping genes GAPDH and CAP-I. Dose response curves were drawn and the $\mathrm{EC}_{50}(\mathbf{A})$ and $\mathrm{IC}_{50}(\mathbf{B})$ values were calculated.

Note: Box plots with whiskers identifying outliers I.5 times the IQR either above the 3rd quartile or below the Ist quartile are shown from 9 individuals.

Abbreviations: LPS, lipopolysaccharide; PCR, polymerase chain reaction; GR, glucocorticoid receptor; GILZ, glucocorticoid inducible leucine zipper; IL-6, interleukin 6;TNF $\alpha$, tumor necrosis factor $\alpha$; GAPDH, glyceraldehyde-3-phosphate dehydrogenase; CAP-I, cyclic AMP-accessory protein; $\mathrm{EC}_{50}$, half maximal effective concentration; $I C_{50}$, half maximal inhibitory concentration; $I Q R$, interquartile range.

$63 \%-96 \%$ (CV of 0.113$),$ TNF $\alpha$ by $44 \%-85 \%$ (CV of 0.211$)$ and IFN $\gamma$ by $84 \%-98 \%$ (CV of 0.053$)$.

In order to test whether the relative efficacy for glucocorticoids was also varied between subjects, whole blood (Figure 2A and B) was stimulated with increasing concentrations of dexamethasone in the presence or absence of $1 \mathrm{ng} / \mathrm{mL}$ LPS for 2 hours, RNA was isolated and the expression of GILZ, FKBP51, IL-6, and TNF $\alpha$ was determined by realtime PCR. Dose response curves were drawn and the halfmaximal effective concentration $\left(\mathrm{EC}_{50}\right)$ and half-maximal inhibitory concentration $\left(\mathrm{IC}_{50}\right)$ values calculated. As can be seen in Figure $2 \mathrm{~A}$ and $\mathrm{B}$, the $\mathrm{IC}_{50}$ and $\mathrm{EC}_{50}$ values are tightly clustered with the exception of the odd outlier (observations more than 1.5 times the IQR either above the 3rd quartile or below the 1st quartile). The CV was 1.029 for GILZ, 0.556 for FKBP51, 3.086 for IL-6, and 2.43 for TNF $\alpha$.
Table 3 Coefficient of variation over gene

\begin{tabular}{llllll}
\hline Gene & Form & Figure & CV & Median & IQR \\
\hline GILZ & $\Delta \Delta C T$ & I & 0.149 & -2.24 & -2.39 to -2.05 \\
FKBP5I & $\Delta \Delta C T$ & I & 0.306 & -2.2 I & -2.27 to -1.82 \\
FLAP & $\Delta \Delta C T$ & I & 0.460 & -0.62 & -0.8 I to -0.43 \\
MKP-I & $\Delta \Delta C T$ & $\mathrm{I}$ & 0.462 & -1.60 & -1.87 to -0.93 \\
IL6 & Repression & $\mathrm{I}$ & 0.113 & 92.9 & 87.6 to 94.8 \\
TNF $\alpha$ & Repression & $\mathrm{I}$ & $0.21 \mathrm{I}$ & 71.0 & 59.5 to 82.3 \\
IFN $\gamma$ & Repression & $\mathrm{I}$ & 0.053 & 93.1 & 88.0 to 95.4 \\
GILZ & $\mathrm{EC}_{50}$ & 2 & 1.029 & 5.26 & $\mathrm{I} .78$ to 6.58 \\
FKBP5I & $\mathrm{EC}_{50}$ & 2 & 0.556 & 21.0 & $\mathrm{I} .9$ to 37.8 \\
IL-6 & $\mathrm{IC}_{50}$ & 2 & 3.086 & 0.03 & 0.00 to $0.1 \mathrm{I}$ \\
TNF $\alpha$ & $\mathrm{IC}_{50}$ & 2 & 2.430 & 0.88 & 0.59 to 2.24 \\
\hline
\end{tabular}

Abbreviations: GILZ, glucocorticoid inducible leucine zipper; FKBP5I, FK506 binding protein 5I; FLAP, arachidonate 5-lipoxygenase-activating protein; MKP-I, mitogen activated protein kinase phosphatase I; IL-6, interleukin 6; TNF $\alpha$, tumor necrosis factor $\alpha$; IFN $\gamma$, interferon $\gamma$.

\section{Diurnal variation of GR function}

Given the natural diurnal cortisol cycle, we next tested the effect of time of day on this assay. Whole blood from 10 individuals (Figure 3) was drawn at 8:30 am, 12:30 pm, 4:30 pm, and 8:30 pm \pm 1 hour and was stimulated with $100 \mathrm{nM}$ dexamethasone in the presence or absence of $1 \mathrm{ng} / \mathrm{mL}$ LPS for 2 hours. RNA was isolated and the expression of the GR upregulated genes GILZ (Figure 3A) and FKBP51 (Figure 3B) and the GR downregulated genes IL-6 (Figure 3C) and TNF $\alpha$ (Figure 3D) determined by realtime PCR. The GR upregulated genes showed a significant increase in their induction (decrease in $\Delta \Delta \mathrm{Ct}$ ) by $100 \mathrm{nM}$ dexamethasone across the duration of the day (GILZ $\Delta \Delta \mathrm{Ct}$ slope $-0.04, P$-value 0.002; FKBP51 $\Delta \Delta \mathrm{Ct}$ slope -0.06 , $P$-value $<0.001)$. Dexamethasone suppression of LPSinduced IL-6 significantly increased from 8:30 am to 12:30 pm ( $\Delta \Delta \mathrm{Ct}$ slope $1.69, P$-value 0.019$)$ but then did not alter for the remainder of the day. Dexamethasone suppression of LPS-induced TNF $\alpha$ was not significantly altered during the day.

\section{Practicality of the assay}

In order to test the practicality of the assay, given that the assay may not be able to be performed immediately, we tested the effect of storing the blood (in the EDTA tube) in a refrigerator for 24 hours prior to performing the assay. Again, two upregulated and two downregulated genes were tested in 10 individuals (Figure 4). Whole blood was drawn and either the assay was performed immediately (closed squares) or the EDTA tubes were stored at $4^{\circ} \mathrm{C}$ for 24 hours before performing the assay (open squares). As can be seen in Figure 4A and B dexamethasone induction of GILZ and 

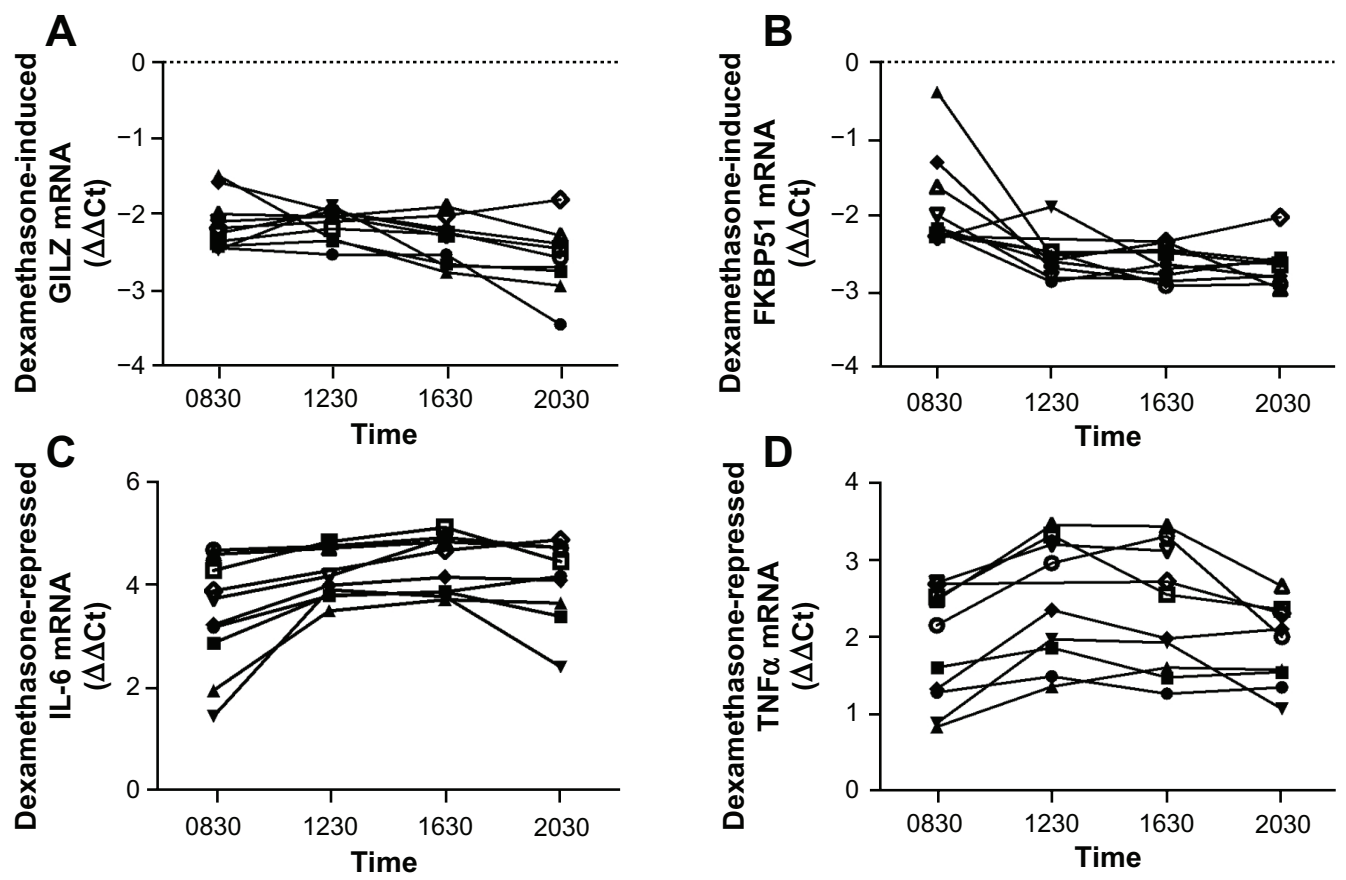

Figure 3 Whole blood was drawn from 10 individuals at 8:30 am, I2:30 pm, 4:30 pm, and 8:30 pm and was stimulated with I00 nM dexamethasone (A and B) or I ng/mL LPS with and without $100 \mathrm{nM}$ dexamethasone (C and D) for 2 hours. RNA was isolated and cDNA transcribed. Real-time PCR was performed to determine expression of the GR upregulated genes GILZ (A) and FKBP5I (B) and the GR downregulated genes IL-6 (C) and TNF $\alpha$ (D).

Notes: The expression of these genes was normalized to the housekeeping genes GAPDH and CAP-I. $\triangle \Delta C t$ was calculated for GILZ and FKBP5I as treatment (dexamethasone) against no treatment and for IL-6 and TNF $\alpha$ as treatment (dexamethasone + LPS) against LPS only. The slope of the $\Delta \Delta C t$ value was calculated and tested for significance using a random-effects linear regression analysis.

Abbreviations: LPS, lipopolysaccharide; PCR, polymerase chain reaction; GR, glucocorticoid receptor; GILZ, glucocorticoid inducible leucine zipper; FKBP5I, FK506 binding protein 5I; IL-6, interleukin 6; TNF $\alpha$, tumor necrosis factor $\alpha$; GAPDH, glyceraldehyde-3-phosphate dehydrogenase; CAP-I, cyclic AMP-accessory protein; $\Delta \Delta \mathrm{Ct}$, comparative cycle threshold.

FKBP51 and dexamethasone suppression of LPS-induced IL-6 and TNF $\alpha$ was considerably different in the sample that had been stored for 24 hours compared to the sample that was analyzed fresh.

Finally, we compared this assay to the dexamethasone suppression of LPS-induced cytokines analyzed by ELISA, which has been previously used. Whole blood was stimulated with $100 \mathrm{nM}$ dexamethasone in the presence or absence of $1 \mathrm{ng} / \mathrm{mL}$ LPS for either 2 or 24 hours. After 2 hours RNA was isolated, cDNA prepared, and the expression of IL-6 mRNA determined by real-time PCR (circles). After 24 hours, serum was separated and IL- 6 protein levels were determined by ELISA (squares). As can be seen in Figure 5 the extent of repression of LPS-induced IL-6 production is comparable between these two different assays.

\section{Discussion}

We have shown that ex vivo stimulation of whole blood can be used to assess GR function by interrogating known GR up- and downregulated genes. Figure 1 shows that there is considerable interpersonal variation in the maximal induction or repression of these genes. However, there is less variability in the $\mathrm{EC}_{50}$ and $\mathrm{IC}_{50}$ values (Figure 2) suggesting that the relative efficacy for dexamethasone is similar between individuals but the extent of the response is varied. These data also indicate that glucocorticoid induction of GR upregulated genes increases throughout the course of the day, when serum cortisol levels are decreasing, but that glucocorticoid suppression of LPS-induced cytokines is relatively unchanged during the day (Figure 3). In our studies, the subject had not eaten for 1 hour before the blood draw (self-reported) but food intake, as well as other factors, could affect the outcome of this assay. Therefore, it is necessary to control that as many factors as possible (such as time of day and food intake) remain constant when making comparisons either between different individuals or within the same person. In an attempt to address the practicability of this assay, we assessed if blood could be stored in the collection tubes prior to performing the assay. The data in Figure 4 would suggest that it is not possible and further work would be needed to identify conditions, which would allow for prolonged storage prior to the assay. Indeed, another study suggested that delayed processing decreased glucocorticoid sensitivity. ${ }^{46}$ Finally, we compared the glucocorticoid suppression of LPS-induced cytokines measured by real-time PCR and ELISA (Figure 5). Comparable results were found with 


\section{A}

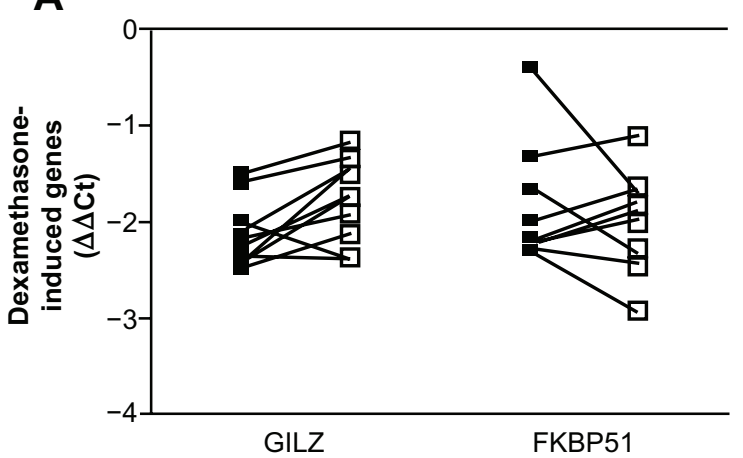

B

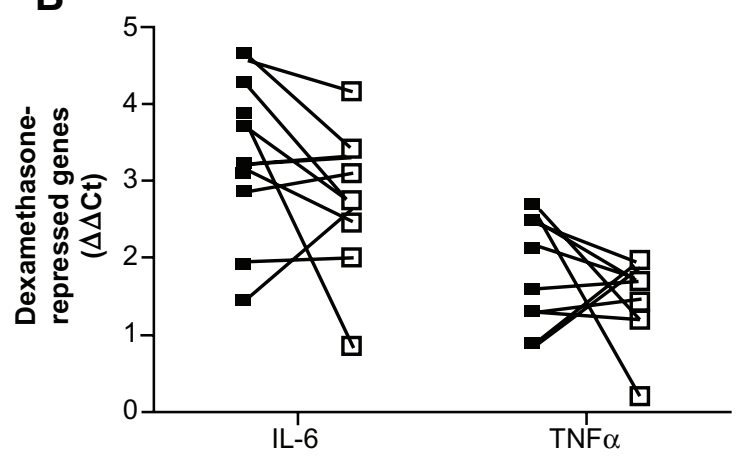

Figure 4 Whole blood from 10 individuals was either treated immediately (closed square) or stored in the EDTA tube at $4^{\circ} \mathrm{C}$ for 24 hours (open square) prior to stimulation with $100 \mathrm{nM}$ dexamethasone (A) or I $\mathrm{ng} / \mathrm{mL}$ LPS with and without $100 \mathrm{nM}$ dexamethasone (B) for 2 hours. RNA was isolated and cDNA transcribed. Real-time PCR was performed to determine the expression of the GR upregulated genes GILZ and FKBP5 I (A) and the GR downregulated genes IL-6 and TNF $\alpha(\mathbf{B})$.

Notes: The expression of these genes was normalized to the housekeeping genes GAPDH and CAP-I. $\triangle \triangle \mathrm{Ct}$ was calculated for GILZ and FKBP5I as treatment (dexamethasone) against no treatment and for IL-6 and TNF $\alpha$ as treatment (dexamethasone + LPS) against LPS only.

Abbreviations: LPS, lipopolysaccharide; PCR, polymerase chain reaction; GR, glucocorticoid receptor; GILZ, glucocorticoid inducible leucine zipper; FKBP5I, FK506 binding protein 5I; IL-6, interleukin 6; TNF $\alpha$, tumor necrosis factor $\alpha$; GAPDH, glyceraldehyde-3-phosphate dehydrogenase; CAP-I, cyclic AMP-accessory protein; $\Delta \Delta \mathrm{Ct}$, comparative cycle threshold.

these two different assays. One pitfall of the current study is that we have used whole blood. Although this provides a fast approach, it does not account for differences in cell populations within the white blood cells, which could play a role in interpersonal variability.

For this assay, we chose to assess both GR up- and downregulated genes. Glucocorticoid suppression of inflammatory-induced genes and/or proteins has been commonly used $^{21,24,25,32-37,46}$ but this only assesses one mechanism through which glucocorticoids function. Surprisingly few studies have chosen to use GR upregulated genes. ${ }^{29}$ In addition, only a couple of groups have incorporated the use of both GR up- and downregulated genes..$^{26,30,47}$ No correlation was found between glucocorticoid suppression of IL-2 and glucocorticoid induction of GILZ, ${ }^{26,30}$ agreeing with our suggestion

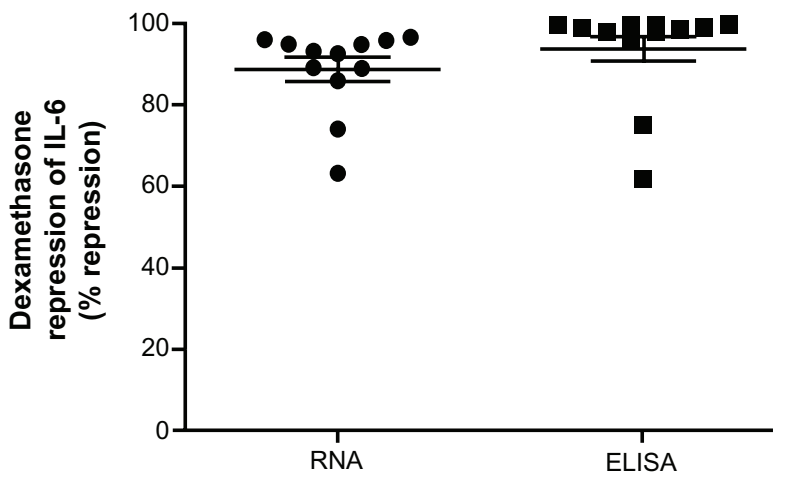

Figure 5 Whole blood was drawn at 8:30 am and stimulated with I ng/mL LPS with and without $100 \mathrm{nM}$ dexamethasone for 2 hours for real-time PCR or 24 hours for ELISA.

Notes: For real-time PCR, RNA was isolated, cDNA transcribed, and real-time PCR performed to determine expression of IL-6 mRNA. The expression of IL-6 was normalized to the housekeeping genes GAPDH and CAP-I. For ELISA, serum was separated and IL-6 protein determined using the Human IL-6 ELIZA MAX Set Deluxe Kit (Biolegend). Upon stimulation with I ng/mL, $702 \pm 922$ pg/mL IL-6 was detected. When co-stimulated with dexamethasone $19 \pm 22 \mathrm{pg} / \mathrm{mL}$ IL-6 was detected. The percentage repression by dexamethasone was calculated by the difference in fold induction by LPS with and without dexamethasone as a percentage of the fold induction by LPS alone. Means and SD are shown from 12 individuals. The two groups were tested for significance using a student's $t$-test.

Abbreviations: LPS, lipopolysaccharide; PCR, polymerase chain reaction; ELISA, enzyme-linked immunosorbent assay; IL-6, interleukin 6; GAPDH, glyceraldehyde3-phosphate dehydrogenase; CAP-I, cyclic AMP-accessory protein; SD, standard deviation.

that it would be more appropriate to assess a combination of both up- and downregulated genes as some GR upregulated genes, such as GILZ ${ }^{40-43}$ and MKP- $1,{ }^{44}$ also play a role in the anti-inflammatory properties of glucocorticoids.

Other assays that have been used include the dexamethasone suppression test, ${ }^{20-25}$ which measures the response of the adrenal glands to adrenocorticotropic hormone; inhibition of stimulated PBMC proliferation, ${ }^{20,27-30}$ which correlates with the response to glucocorticoid therapy in some diseases; $;^{12,13,48,49}$ quantification of the number and affinity of GR in the PBMCs, ${ }^{20,30,31}$ bioinformatics profiling; ${ }^{37,38}$ and cutaneous vasoconstrictor (skin blanching), ${ }^{21,39}$ which determines topical potency of glucocorticoids. Attempts to obtain concordance between many of these assays have failed. Chriguer et al compared the dexamethasone suppression test, PBMC proliferation assay, and the numbers of GR in normal healthy volunteers. They found concordance between these assays in the majority of people but in a few there was no concordance suggesting possible tissuespecific glucocorticoid sensitivity. ${ }^{20}$ Ebrecht et al found no concordance between the dexamethasone suppression of LPS-induced cytokines, skin blanching, and the dexamethasone suppression test in healthy volunteers, again suggesting target tissue specificity. ${ }^{21}$ Vasiliadi et al also found no concordance between the dexamethasone suppression test 
Table 4 Descriptive statistics by figure, gene, and time

\begin{tabular}{lllll}
\hline Figure & Gene & Time & Median & IQR \\
\hline 3 & FKBP5I & 0 & -2.18 & -2.26 to -1.63 \\
3 & FKBP5I & 4 & -2.59 & -2.69 to -2.48 \\
3 & FKBP5I & 8 & -2.67 & -2.83 to -2.45 \\
3 & FKBP5I & 12 & -2.65 & -2.82 to -2.6 I \\
3 & GILZ & 0 & -2.21 & -2.42 to -2.00 \\
3 & GILZ & 4 & -2.03 & -2.33 to -1.97 \\
3 & GILZ & 8 & -2.27 & -2.66 to -2.20 \\
3 & GILZ & I2 & -2.58 & -2.75 to -2.39 \\
3 & IL-6 & 0 & 90.9 & 86.3 to 94.9 \\
3 & IL-6 & 4 & 93.7 & 92.8 to 96.2 \\
3 & IL-6 & 8 & 94.0 & 93.1 to 96.7 \\
3 & IL-6 & I2 & 94.5 & 92.0 to 96.2 \\
3 & TNF $\alpha$ & 0 & 72.2 & 58.9 to 82.5 \\
3 & TNF $\alpha$ & 4 & 80.4 & 72.4 to 89.2 \\
3 & TNF $\alpha$ & 8 & 78.8 & 66.9 to 88.5 \\
3 & TNF $\alpha$ & I2 & 75.0 & 65.8 to 79.8 \\
4 & FKBP5I & Pre & -2.18 & -2.26 to -1.63 \\
4 & FKBP5I & Post & -1.92 & -2.42 to -1.70 \\
4 & GILZ & Pre & -2.21 & -2.42 to -2.00 \\
4 & GILZ & Post & -1.73 & -2.12 to -1.45 \\
4 & IL6 & Pre & 90.9 & 86.3 to 94.9 \\
4 & IL6 & Post & 84.7 & 81.8 to 90.0 \\
4 & TNF $\alpha$ & Pre & 72.2 & 58.9 to 82.5 \\
4 & TNF $\alpha$ & Post & 68.6 & 57.5 to 72.5 \\
5 & IL-6 & Pre & 90.9 & 83.6 to 94.0 \\
5 & IL-6 & Post & 98.9 & 96.6 to 99.7 \\
\hline A & & &
\end{tabular}

Abbreviations: IQR, interquartile range; FKBP5I, FK506 binding protein 51 GILZ, glucocorticoid inducible leucine zipper; IL-6, interleukin 6; TNF $\alpha$, tumor necrosis factor $\alpha$.

and dexamethasone inhibition of LPS-induced TNF $\alpha^{25}$ and Smit et al found no concordance between the dexamethasone suppression test and expression of GR up- and downregulated genes. ${ }^{26}$ Concordance between the cutaneous vasoconstrictor assay and glucocorticoid sensitivity in asthma has been varied. $^{39,50}$

Others have shown that there is considerable interpersonal variability in glucocorticoid responses. $23,25,26,29,30,46,51$ Interestingly, serum cortisol did not correlate with genomewide transcriptional analysis of GR and NFKB-regulated genes. ${ }^{38} \mathrm{~A}$ few studies have investigated the effect of the diurnal cortisol cycle on these assays but with conflicting results. No difference in dexamethasone suppression of LPS-induced cytokines in the evening or morning was seen in one study. ${ }^{32}$ In another, increased glucocorticoid inhibition of LPS-induced TNF $\alpha$ was seen in the morning compared to the evening hours. ${ }^{35}$ However, both these studies pooled several individuals and are confounded by possible interpersonal variations. Recently, a study has described differences in glucocorticoid sensitivity in morning and afternoon samples but comparison within the same individual was not made. ${ }^{46}$ Again, confounding factors could also affect the outcome of this and other GR functional assays, including stress (social isolation stress), ${ }^{38,52}$ depression, ${ }^{53,54}$ exercise, ${ }^{34}$ and disease state. ${ }^{33}$

\section{Conclusion}

We suggest that this assay could be used to determine glucocorticoid sensitivity. One caveat is that this assay will not be able to determine differences in glucocorticoid sensitivity in a person if it is tissue specific. However, if it is possible for viable cells to be obtained from the tissue of interest, for example by bronchoalveolar lavage, ${ }^{36}$ then this assay may prove useful in analyzing tissue specific responsiveness.

\section{Acknowledgments/disclosure}

The authors report no conflicts of interest in this work. We would like to thank Tim Eubank for assistance with blood draws, Mikhail Gavrilin for the IL-6, IFN $\gamma$, and TNF $\alpha$ primers, and Dr Mark Wewers for critically reading this manuscript.

\section{References}

1. van Staa TP, Leufkens HG, Abenhaim L, Begaud B, Zhang B, Cooper C. Use of oral corticosteroids in the United Kingdom. QJM. 2000;93(2):105-111.

2. Webster JI, Tonelli L, Sternberg EM. Neuroendocrine regulation of immunity. Annu Rev Immunol. 2002;20:125-163.

3. Aranda A, Pascual A. Nuclear hormone receptors and gene expression. Physiol Rev. 2001;81(3):1269-1304.

4. Schoneveld OJ, Gaemers IC, Lamers WH. Mechanisms of glucocorticoid signalling. Biochim Biophys Acta. 2004;1680(2):114-128.

5. Hayashi R, Wada H, Ito K, Adcock IM. Effects of glucocorticoids on gene transcription. Eur J Pharmacol. 2004;500(1-3):51-62.

6. Schäcke H, Döcke WD, Asadullah K. Mechanisms involved in the side effects of glucocorticoids. Pharmacol Ther. 2002;96(1):23-43.

7. Jensen AØ, Thomsen HF, Engebjerg MC, et al. Use of oral glucocorticoids and risk of skin cancer and non-Hodgkin's lymphoma: a populationbased case-control study. Br J Cancer. 2009;100(1):200-205.

8. Wei L, MacDonald TM, Walker BR. Taking glucocorticoids by prescription is associated with subsequent cardiovascular disease. Ann Intern Med. 2004;141(10):764-770.

9. Steinbuch M, Youket TE, Cohen S. Oral glucocorticoid use is associated with an increased risk of fracture. Osteoporos Int. 2004;15(4): 323-328.

10. Klein $\mathrm{NC}$, Go $\mathrm{CH}$, Cunha BA. Infections associated with steroid use. Infect Dis Clin North Am. 2001;15(2):423-432.

11. Buttgereit F, Saag KG, Cutolo M, da Silva JA, Bijlsma JW. The molecular basis for the effectiveness, toxicity, and resistance to glucocorticoids: focus on the treatment of rheumatoid arthritis. Scand J Rheumatol. 2005;34(1):14-21.

12. Corrigan CJ, Brown PH, Barnes NC, et al. Glucocorticoid resistance in chronic asthma. Glucocorticoid pharmacokinetics, glucocorticoid receptor characteristics, and inhibition of peripheral blood T cell proliferation by glucocorticoids in vitro. Am Rev Respir Dis. 1991;144(5):1016-1025.

13. Hearing SD, Norman M, Probert CS, Haslam N, Dayan CM. Predicting therapeutic outcome in severe ulcerative colitis by measuring in vitro steroid sensitivity of proliferating peripheral blood lymphocytes. Gut. 1999;45(3):382-388. 
14. Leung DY, de Castro M, Szefler SJ, Chrousos GP. Mechanisms of glucocorticoid-resistant asthma. Ann N Y Acad Sci. 1998;840: $735-746$.

15. Seki M, Ushiyama C, Seta N, et al. Apoptosis of lymphocytes induced by glucocorticoids and relationship to therapeutic efficacy in patients with systemic lupus erythematosus. Arthritis Rheum. 1998;41(5): $823-830$.

16. van Schaardenburg D, Valkema R, Dijkmans BA, et al. Prednisone treatment of elderly-onset rheumatoid arthritis. Disease activity and bone mass in comparison with chloroquine treatment. Arthritis Rheum. 1995;38(3):334-342.

17. Hearing SD, Norman M, Smyth C, Foy C, Dayan CM. Wide variation in lymphocyte steroid sensitivity among healthy human volunteers. J Clin Endocrinol Metab. 1999;84(11):4149-4154.

18. Marik PE, Pastores SM, Annane D, et al; for American College of Critical Care Medicine. Recommendations for the diagnosis and management of corticosteroid insufficiency in critically ill adult patients: consensus statements from an international task force by the American College of Critical Care Medicine. Crit Care Med. 2008;36(6): 1937-1949.

19. Turner D, Kolho KL, Mack DR, et al. Glucocorticoid bioactivity does not predict response to steroid therapy in severe pediatric ulcerative colitis. Inflamm Bowel Dis. 2010;16(3):469-473.

20. Chriguer RS, Elias LL, da Silva IM Jr, Vieira JG, Moreira AC, de Castro M. Glucocorticoid sensitivity in young healthy individuals: in vitro and in vivo studies. $J$ Clin Endocrinol Metab. 2005;90(11): 5978-5984.

21. Ebrecht M, Buske-Kirschbaum A, Hellhammer D, et al. Tissue specificity of glucocorticoid sensitivity in healthy adults. $J$ Clin Endocrinol Metab. 2000;85(10):3733-3739.

22. Faria CD, Cobra JF, Sousa E, Silva T, et al. A very low dose intravenous dexamethasone suppression test as an index of glucocorticoid sensitivity. Horm Res. 2008;69(6):357-362.

23. Huizenga NA, Koper JW, de Lange P, et al. Interperson variability but intraperson stability of baseline plasma cortisol concentrations, and its relation to feedback sensitivity of the hypothalamo-pituitary-adrenal axis to a low dose of dexamethasone in elderly individuals. $J$ Clin Endocrinol Metab. 1998;83(1):47-54.

24. Syed AA, Redfern CP, Weaver JU. In vivo and in vitro glucocorticoid sensitivity in obese people with cushingoid appearance. Obesity (Silver Spring). 2008;16(10):2374-2378.

25. Vasiliadi D, Gratsias Y, Tsagarakis S, et al. Glucocortidoid sensitivity assessed in peripheral blood cells do not correlate with the feedback sensitivity of the hypothalamo-pituitary adrenal AXIS. Hormones (Athens). 2002;1(4):233-238.

26. Smit P, Russcher H, de Jong FH, Brinkmann AO, Lamberts SW, Koper JW. Differential regulation of synthetic glucocorticoids on gene expression levels of glucocorticoid-induced leucine zipper and interleukin-2. J Clin Endocrinol Metab. 2005;90(5):2994-3000.

27. Creed TJ, Lee RW, Newcomb PV, di Mambro AJ, Raju M, Dayan CM. The effects of cytokines on suppression of lymphocyte proliferation by dexamethasone. J Immunol. 2009;183(1):164-171.

28. Sliwinska-Stanczyk P, Pazdur J, Ziolkowska M, Jaworski J, Kaminska-Tchorzewska E, Lacki JK. The effect of methylprednisolone on proliferation of PBMCs obtained from steroid-sensitive and steroid-resistant rheumatoid arthritis patients. Scand J Rheumatol. 2007;36(3):167-171.

29. Vermeer H,Hendriks-Stegeman BI, Verrijn StuartAA, van Buul-Offers SC, Jansen M. A comparison of in vitro bioassays to determine cellular glucocorticoid sensitivity. Eur J Endocrinol. 2004;150(1):41-47.

30. Russcher H, Smit P, van Rossum EF, et al. Strategies for the characterization of disorders in cortisol sensitivity. J Clin Endocrinol Metab. 2006;91(2):694-701.

31. Ioannesyants IA, Polevaya EB. Sensitivity of peripheral blood lymphocytes from breast cancer patients to glucocorticoids. Bull Exp Biol Med. 2006;141(1):73-76.
32. De Rijk R, Michelson D, Karp B, et al. Exercise and circadian rhythminduced variations in plasma cortisol differentially regulate interleukin-1 beta (IL-1 beta), IL-6, and tumor necrosis factor-alpha (TNF alpha) production in humans: high sensitivity of TNF alpha and resistance of IL-6. JClin Endocrinol Metab. 1997;82(7):2182-2191.

33. DeRijk RH, Eskandari F, Sternberg EM. Corticosteroid resistance in a subpopulation of multiple sclerosis patients as measured by ex vivo dexamethasone inhibition of LPS induced IL-6 production. J Neuroimmunol. 2004;151(1-2):180-188.

34. DeRijk RH, Petrides J, Deuster P, Gold PW, Sternberg EM. Changes in corticosteroid sensitivity of peripheral blood lymphocytes after strenuous exercise in humans. J Clin Endocrinol Metab. 1996;81(1):228-235.

35. Gratsias Y, Moutsatsou P, Chrysanthopoulou G, Tsagarakis S, Thalassinos N, Sekeris CE. Diurnal changes in glucocorticoid sensitivity in human peripheral blood samples. Steroids. 2000;65(12):851-856.

36. Armstrong J, Sargent C, Singh D. Glucocorticoid sensitivity of lipopolysaccharide-stimulated chronic obstructive pulmonary disease alveolar macrophages. Clin Exp Immunol. 2009;158(1):74-83.

37. Hakonarson H, Bjornsdottir US, Halapi E, et al. Profiling of genes expressed in peripheral blood mononuclear cells predicts glucocorticoid sensitivity in asthma patients. Proc Natl Acad Sci U S A. 2005;102(41):14789-14794.

38. Cole SW, Hawkley LC, Arevalo JM, Sung CY, Rose RM, Cacioppo JT. Social regulation of gene expression in human leukocytes. Genome Biol. 2007;8(9):R189.

39. Brown PH, Teelucksingh S, Matusiewicz SP, Greening AP, Crompton GK, Edwards CR. Cutaneous vasoconstrictor response to glucocorticoids in asthma. Lancet. 1991;337(8741):576-580.

40. Ayroldi E, Riccardi C. Glucocorticoid-induced leucine zipper (GILZ): a new important mediator of glucocorticoid action. FASEB J. 2009;23(11):3649-3658.

41. Eddleston J, Herschbach J, Wagelie-Steffen AL, Christiansen SC, Zuraw BL. The anti-inflammatory effect of glucocorticoids is mediated by glucocorticoid-induced leucine zipper in epithelial cells. J Allergy Clin Immunol. 2007;119(1):115-122.

42. Cannarile L, Zollo O, D'Adamio F, et al. Cloning, chromosomal assignment and tissue distribution of human GILZ, a glucocorticoid hormone-induced gene. Cell Death Differ. 2001;8(2):201-203.

43. D'Adamio F, Zollo O, Moraca R, et al. A new dexamethasone-induced gene of the leucine zipper family protects T lymphocytes from TCR/ CD3-activated cell death. Immunity. 1997;7(6):803-812.

44. Li L, Chen SF, Liu Y. MAP kinase phosphatase-1, a critical negative regulator of the innate immune response. Int J Clin Exp Med. 2009;2(1): $48-67$.

45. Gavrilin MA, Bouak1 IJ, Knatz NL, et al. Internalization and phagosome escape required for Francisella to induce human monocyte IL-1beta processing and release. Proc Natl Acad Sci U S A. 2006;103(1):141-146.

46. Cardinal J, Pretorius CJ, Ungerer JP. Biological and diurnal variation in glucocorticoid sensitivity detected with a sensitive in vitro dexamethasone suppression of cytokine production assay. J Clin Endocrinol Metab. 2010;95(8):3657-3663.

47. Macedo JA, Hesse J, Turner JD, Meyer J, Hellhammer DH, Muller CP. Glucocorticoid sensitivity in fibromyalgia patients: decreased expression of corticosteroid receptors and glucocorticoid-induced leucine zipper. Psychoneuroendocrinology. 2008;33(6):799-809.

48. Alvarez J, Surs W, Leung DY, Iklé D, Gelfand EW, Szefler SJ. Steroidresistant asthma: immunologic and pharmacologic features. $J$ Allergy Clin Immunol. 1992;89(3):714-721.

49. Kirkham BW, Corkill MM, Davison SC, Panayi GS. Response to glucocorticoid treatment in rheumatoid arthritis: in vitro cell mediated immune assay predicts in vivo responses. $J$ Rheumatol. 1991;18(6):821-825.

50. Wilson AM, Coutie WJ, Sims EJ, Lipworth BJ. The skin vasoconstrictor assay does not correlate significantly to airway or systemic responsiveness to inhaled budesonide in asthmatic patients. Eur J Clin Pharmacol. 2003;58(10):643-647. 
51. Rohleder N, Wolf JM, Kirschbaum C. Glucocorticoid sensitivity in humans-interindividual differences and acute stress effects. Stress. 2003;6(3):207-222.

52. Cole SW. Social regulation of leukocyte homeostasis: the role of glucocorticoid sensitivity. Brain Behav Immun. 2008;22(7):1049-1055.
53. Miller GE, Rohleder N, Stetler C, Kirschbaum C. Clinical depression and regulation of the inflammatory response during acute stress. Psychosom Med. 2005;67(5):679-687.

54. Pariante CM. Glucocorticoid receptor function in vitro in patients with major depression. Stress. 2004;7(4):209-219.

Journal of Inflammation Research

\section{Publish your work in this journal}

The Journal of Inflammation Research is an international, peer-reviewed open-access journal that welcomes laboratory and clinical findings on the molecular basis, cell biology and pharmacology of inflammation including original research, reviews, symposium reports, hypothesis formation and commentaries on: acute/chronic inflammation; mediators of inflamma-
Dovepress

tion; cellular processes; molecular mechanisms; pharmacology and novel anti-inflammatory drugs; clinical conditions involving inflammation. The manuscript management system is completely online and includes a very quick and fair peer-review system. Visit http://www.dovepress.com/ testimonials.php to read real quotes from published authors.

\footnotetext{
Submit your manuscript here: http://www.dovepress.com/journal-of-inflammation-research-journal
} 